DOI: 10.31392/NPU-nc.series14.2019.27.20

УДК 37:78:167-047.37

Цюй Ге

\title{
Синергетичний підхід: сутність і характерні особливості застосування в наукових дослідженнях 3 педагогіки мистецтва
}

\begin{abstract}
Синергетичний підхід окреслено в якості однієї з методологічних основ, що спрямовують сучасні мистецько-педагогічні дослідження у русло еволюційного розвитку і самоорганізації складних систем, дозволяють окреслити нову парадигму сучасної педагогіки мистецтва, направляють пї на розвиток креативності особистості. Визначено поняття «синергетика» як міждисциплінарний напрямок наукових досліджень у галузі складних еволюціонуючих систем. Синергетичний підхід актуалізує такий напрямок розвитку педагогічної науки, як педагогічна синергетика. Недостатньо дослідженим є потенціал синергетичного підходу щодо розвитку мотиваційної сфери майбутнього вчителя музичного мистецтва до навчально-виконавської діяльності в процесі інструментальної підготовки. Окреслено сукупність характерних для синергетичного підходу специфічних категорій. Розглянуто деякі з цих категорій у контексті формування мотивації до навчально-виконавської діяльності як основи подальшої ефективності фахової діяльності вчителя мистецтва.
\end{abstract}

Ключові слова: творчий саморозвиток особистості; синергетика; мотивація до навчальновиконавської діяльності; самоорганізація; синергетична парадигма; педагогіка мистецтва.

Пришвидшення темпів сьогодення, яке відбувається в сучасному соціумі, призводить до змін практично в усіх сферах життя людини, а також супроводжується перманентним розширенням інформаційно-комунікаційного простору, який привносить елементи інноватики в абсолютно усі напрямки діяльності особистості. В таких умовах перед сучасною педагогікою загалом і педагогікою мистецтва зокрема постає проблема щодо формування такої особистості педагога, який би не просто встигав за соціально-суспільними, технологічними змінами, а зміг би стати провідником означених змін у закладах середньої та вищої освіти. Для цього необхідною є опора сучасних науково-педагогічних досліджень на такі методологічні основи, які уможливлюють швидкий і потужний рух сучасної мистецької педагогіки. До таких методологічних основ, безумовно, належить синергетичний підхід, що спрямовує мистецько-педагогічні дослідження у русло еволюційного розвитку i самоорганізації складних систем, до яких належить і особистість 3 iї складними, багатофункціональними психолого-фізіологічними та хімічно-біологічними сторонами існування.

Саме синергетичний підхід дозволяє окреслити нову парадигму сучасної педагогіки мистецтва, яка, оновлюючи усю концептуальну схему мистецького навчання, модернізуючи загальну модель постановки й розв'язання освітніх проблем, спрямовує їх на розвиток креативності й гнучкості мислення особистості. Адже саме креативність і гнучкість мислення забезпечить адаптацію до перманентної змінності, якою характеризується сучасний етап суспільного розвитку. 3 огляду на вищезазначене, можна стверджувати стрімке зростання актуальності застосування синергетичного підходу до сучасних мистецько-педагогічних досліджень.

3 метою визначення сутності синергетичного підходу доцільно, на нашу думку, окреслити поняття «синергетика», яким характеризується певний міждисциплінарний напрямок наукових досліджень у галузі складних еволюціонуючих систем, започаткований Г.Хагеном та І.Пригожиним у 70-х роках минулого століття. С Гончаренко зазначає, що синергетика ставить за мету «...пізнання загальних принципів самоорганізації систем різної природи - від фізичних до соціальних, аби лише вони мали такі властивості, як відкритість, нелінійність, нерівноважність, здатність підсилювати випадкові флуктуації» [2, 420]. Вчений визначає в якості предмету синергетики «...прямі і зворотні переходи систем від стабільності до нестабільності, від хаосу до порядку, від руйнування до створення» [2, 420]. 
Проблематика синергетики й синергетичного підходу цікавила багатьох дослідників, зокрема, філософів і педагогів, серед яких: В.Андрущенко, В.Аршинов, В.Буданов, О.Вознюк, Н.Гузій, С.Князева, І.Кудрявцев, С.Курдюмов, В.Кремень, Н.Сегеда, Л.Ткаченко, Є.Ямбург та ін.

Зважаючи на те, що педагогічна наука оперує великою кількістю різноманітних систем педагогічних, освітніх, методичних, методологічних тощо, а також на проникнення синергетичної парадигми мислення у педагогічну думку кінця двадцятого - початку двадцять першого століття, доцільно стверджувати, що синергетичний підхід не тільки набуває значення однієї з найбільш задіяних методологічних основ розвитку педагогічної науки, але й актуалізує такий її напрямок, як педагогічна синергетика.

У той же час, незважаючи на зростання наукового інтересу до цієї тематики, і проблема синергетичного підходу в освіті, i проблема педагогічної синергетики продовжують перебувати у стані наукового пошуку, концептуального розроблення. Зокрема, недостатньо дослідженим $\epsilon$ потенціал синергетичного підходу для розвитку мотиваційної сфери майбутніх педагогів-музикантів до навчальної діяльності у музично-педагогічних ЗВО загалом і їх навчально-виконавської діяльності у процесі інструментальної підготовки зокрема.

3 огляду на вищезазначене, метою статті $\epsilon$ визначення сутності та характерних особливостей синергетичного підходу в контексті розвитку мотивації студентів факультетів мистецтв педагогічних університетів до навчально-виконавської діяльності.

О.Вознюк зазначає, що синергетичний підхід у педагогіці «... постає концептуальним базисом як сукупність певних вихідних положень синергетики, згідно яких проводиться теоретичний аналіз педагогічної думки. ...синергетичний підхід акцентує увагу на нагальності розробки нової синергетичної парадигми освіти, що передбачає процес подолання труднощів навчального і педагогічного аспектів педагогічного процесу, які ... розкриваються у нових способах його структурування, оновлених методах викладання, що спираються на самостійну пізнавальну активність...» $[1,14]$.

Низка вчених (О.Вознюк, Є.Князева, М.Нещадим, Є.Пугачова, І.Сенновський, П.Третьяков та ін.) наполягають на складності й багатогранності синергетичного підходу, що виявляється у сукупності характерних для нього специфічних категорій. До них належать: природна самоорганізація, самодетермінованість педагогічних об'єктів; - неврівноважена динаміка, флуктуації, стан нестійкості; - хаотичність процесів; - відкритість (дисипатизм) педагогічних систем, їх саморозвиток, самодетермінізм; - нелінійність, біфуркаційність освітніх процесів; - імовірність, випадковість, банатомірність педагогічних явищ; атракторність педагогічних процесів [1].

Розглянемо деякі 3 наведених вище категорій синергетичного підходу у контексті формування у студентів факультетів мистецтв педагогічних університетів мотивації до навчально-виконавської діяльності як основи подальшої ефективності фахової діяльності вчителя мистецтва.

Отже, визначаючи процес формування в майбутніх учителів мистецтва мотивації до навчально-виконавської діяльності в якості педагогічного об'єкту, доцільно зауважити, що застосування синергетичного підходу не тільки враховує здатність означеного педагогічного об’єкту до природньої самоорганізації, але й уможливлює самоорганізацію власної вмотивованості безпосередньо студентом як суб'єктом навчально-педагогічного процесу.

Неврівноваженість динаміки, флуктуація, стан нестійкості, які відмічають дослідники синергетичного підходу, є вельми характерними для процесу формування у студентів факультетів мистецтв педагогічних університетів мотивації до навчально-виконавської діяльності. Адже на мотиваційні утворення - пізнавальні інтереси, художньо-естетичні потреби у галузі музичного виконавства, установку на отримання знань і умінь у цій галузі та готовність до їх ефективного застосування у подальшій фаховій діяльності - потужно впливають ті чи інші як цілеспрямовані, так і спонтанні зміни не тільки у навчальному 
середовищі, але й в оточуючому світі. Причому такі зміни, як правило, призводять до створення проблемних ситуацій вибору, здатність до розв'язання яких $\epsilon$ надважливим завданням для майбутнього педагога. Хаотичність процесу формування у студентів факультетів мистецтв педагогічних університетів мотивації до навчально-виконавської діяльності у контексті синергетичного підходу обумовлюється сукупністю власних цілеспрямованих бажань і спонтанних настроїв майбутнього вчителя мистецтва, а також наявністю як спеціально створених, так і несподіваних у навчальному процесі проблемних ситуацій із багатоваріантними шляхами їх розв'язання.

Таким чином, розгляд деяких з поданих вище категорій синергетичного підходу у контексті формування в студентів факультетів мистецтв педагогічних університетів мотивації до навчально-виконавської діяльності дозволив конкретизувати сутність та характерні особливості означеного підходу, а саме:

- самоорганізацію у царині формування мотивації до навчально-виконавської діяльності можна визначити як сукупність психолого-педагогічних процесів, що підтримують i стимулюють такі мотиваційні утворення студента як стійкий інтерес до означеної діяльності, поглиблені художньо-естетичні потреби у музичному виконавстві, психологічна установка на набуття сукупності необхідних знань і умінь та готовність до ефективного їх застосування під час фахової діяльності;

- неврівноваженість динаміки, флуктуація, стан нестійкості характеризують сутність синергетичного підходу в якості важливого чинника створення проблемних ситуацій вибору, здатність до розв’язання яких є надважливою для майбутнього педагога;

- хаотичність процесу формування у студентів факультетів мистецтв педагогічних університетів мотивації до навчально-виконавської діяльності окреслює сутність синергетичного підходу з позицій використання творчого потенціалу означеної хаотичності для формування креативності мислення майбутніх фахівців-музикантів.

3 огляду на вищезазначене, прогрес сучасного соціуму на основі синергетичного підходу пропонує мистецькій педагогіці сьогодення нову парадигму перманентного оновлення, що базується на властивій людському інтелекту здатності осмислювати дійсність, трансформувати їі та вносити елемент новизни [3].

Отже, враховуючи те, що синергетичний підхід, спираючись на принципи розвитку складних еволюціонуючих систем, здійснює стратегічну орієнтацію на творчий саморозвиток особистості, доцільно вважати цей підхід однією 3 фундаментальних основ сучасної методології педагогічних досліджень у галузі педагогіки мистецтва.

\section{Література}

1. Андрущенко В.П. Філософічність освіти: теорія, методологія, практика / В.П. Андрущенко // Вища освіта України. 2008. № 4. С.10-18.

2. Вознюк О.В. Розвиток вітчизняної педагогічної думки: синергетичний підхід (друга половина ХХ століття). Навчально-методичний посібник / за ред. проф. П.Ю. Сауха. - Житомир : вид-во ЖДУ, 2008. $128 \mathrm{c}$.

3. Гончаренко С.У. Український педагогічний енциклопедичний словник. Видання друге доповнене й виправлене / Семен Устимович Гончаренко. - Рівне : Волинські обереги, 2011. 519 с.

4. Кремень В.Г. Людиноцентризм в стратегіях освітнього простору / В.Г. Кремень. - Київ : Педагогічна думка, 2009. 520 с.

5. Падалка Г.М. Педагогіка мистецтва (Теорія і методика викладання мистецьких дисциплін) Київ : Освіта України, 2008. 274s.

6. Рудницька О.П. Основи викладання мистецьких дисциплін. - Київ: АПН України, 1998. 183 с.

7. Хуторской А.К. Ключевые компетенции как компонент личностно-ориентированной парадигмы образования. Народное образование. 2003. № 2. С. 58- 64.

8. Шевнюк О.Л. Культурологічна освіта майбутнього вчителя: теорія і практика. - Київ, НПУ ім. М.П. Драгоманова, 2003. 232 с.

9. Щолокова О.П. Основи професійної художньо-естетичної підготовки майбутніх вчителів. Київ, НПУ ім. М.П. Драгоманова, 1996. 172 с. 
10. Яконюк В.Л. Развитие интереса к профессии учителя музыки. - Минск: Высш. школа, 1979. $104 \mathrm{c}$.

Про автора:

Цюй Ге, аспірантка факультету мистецтв Національного педагогічного університету імені М.П. Драгоманова (Київ, Україна); ORCID: 0000-0002-0416-2977, e-mail: 815308713@qq.com

\section{Synergetic approach: the nature and characteristic features of the use of art pedagogy in scientific research}

Qu Ge

The article considers the problem of using the synergetic approach in modern studies of pedagogy of art as an important factor in introducing elements of innovation in all areas of pedagogical science with the aim of forming the personality of the teacher - a conductor of quick and effective changes in secondary and higher education institutions. The synergetic approach is outlined as one of the methodological foundations that direct modern pedagogical research in the direction of evolutionary development and self-organization of complex systems, allow us to identify a new paradigm of modern pedagogy of art, direct it to the development of creative personality. The concept of "synergetic" is defined as an interdisciplinary direction of scientific research in the field of evolving systems. It has been established that the synergetic approach actualizes such a direction in the development of pedagogical science as pedagogical synergetic. It has been examined that synergistic approach and its potential regarding the development of the future music teacher's motivational sphere to teaching and performing were revealed in the process of instrumental preparation. A set of specific categories characteristic of the synergetic approach is outlined. Some of these categories are considered in the context of the formation of students of the faculty of arts of pedagogical universities motivation for learning and performing activities as the basis for further professionalism of an art teacher. The essence and characteristic features of the synergetic approach are specified. The strategic orientation of the synergetic approach to the creative self-development of a person based on the principles of the development of complex evolving systems was stated.

Keywords: creative self-development of a person; synergetic; motivation for training and performing activities; self-organization; synergetic paradigm; pedagogy of art.

\section{References}

1. Andruschenko V.P. Filosofichnist osviti: teoriya, metodologIya, praktika / V.P. Andruschenko // Vischa osvIta UkraYini. 2008. \# 4. S.10-18.

2. Vozniuk O.V. Rozvytok vitchyznianoi pedahohichnoi dumky: synerhetychnyi pidkhid (druha polovyna XX stolittia). Navchalno-metodychnyi posibnyk / za red. prof. P.Iu. Saukha. - Zhytomyr: vyd-vo ZhDU, 2008. $128 \mathrm{~s}$.

3. Honcharenko S.U. Ukrainskyi pedahohichnyi entsyklopedychnyi slovnyk. Vydannia druhe dopovnene y vypravlene / Semen Ustymovych Honcharenko. - Rivne: «Volynski oberehy», 2011. 519 s.

4. Kremen V.H. Liudynotsentryzm $\mathrm{v}$ stratehiiakh osvitnoho prostoru / V.H. Kremen. - Kyiv: Pedahohichna dumka, 2009. $520 \mathrm{~s}$.

5. Padalka G.M. Pedagogika mistetstva (Teoriya i metodika vikladannya mistetskih distsiplin) - Kyiv: Osvita Ukrayini, 2008. 274 s.

6. Rudnitska O.P. Osnovi vikladannya mistetskih distsiplIn. - Kyiv: APN UkraYini, 1998.183s.

7. Hutorskoy A.K. Klyuchevyie kompetentsii kak komponent lichnostno-orientirovannoy paradigmyi obrazovaniya. Narodnoe obrazovanie. 2003. \# 2. S. 58-64.

8. Shevnyuk O.L. Kulturologichna osvita maybutnogo vchitelya: teoriya i praktika. - Kyiv, NPU im. M.P. Dragomanova, 2003. $232 \mathrm{~s}$.

9. Scholokova O.P. Osnovi profesiynoyi hudozhno-estetichnoyi pidgotovki maybutnih vchiteliv. - Kyiv, NPU im. M.P. Dragomanova, 1996. $172 \mathrm{s.}$

10. Yakonyuk V.L. Razvitie interesa k professii uchitelya muziki. - Minsk: Vyissh. shkola, 1979. 104 s.

\section{About the author:}

Qu Ge, postgraduate student at the Faculty of Arts, National Pedagogical Dragomanov University (01054, Kyiv, Ukraine); ORCID: 0000-0002-0416-2977, e-mail: 815308713@qq.com 